\title{
TYK2 Gene
}

National Cancer Institute

\section{Source}

National Cancer Institute. TYK2 Gene. NCI Thesaurus. Code C101546.

This gene is involved in both protein phosphorylation and interferon-mediated signaling. 